Irena Rudziewicz

Olsztyn

\title{
Chłopska przestrzeń życiowa w poetyckich utworach Franciszka Bahuszewicza
}

W twórczości Franciszka Bahuszewicza (1840-1900), jak na całym zróżnicowanym kulturowo, etnicznie, religijnie terenie Białorusi, występują ciasno, nieroztacznie ze soba splecione sprawy religii $i$ bytu narodowego, duchowości i kościoła, chrześcijaństwa i kultury ${ }^{1}$, traktowane w szerokim kontekście spraw ideowych, narodowych, duchowych. Interesujący się białoruskim folklorem, pod wpływem postulatów romantycznych Bahuszewicz wysuwał zróżnicowane idee kulturalne i społeczne, brał na siebie rolę obrońcy ludu białoruskiego, rozmawiał z nim w jego języku, tworząc tym samym zręby nowoczesnej literatury białoruskiej. W biografii poetyckiej Bahuszewicza problematyka chłopska występuje w aspekcie społecznym, ekonomicznym i moralnym. W twórczych dokonaniach Bahuszewicza, poety, prozaika, publicysty, działacza społecznego utrwaliły się różnorodne tendencje, kierunki i pytania, myśli i zespoły idei filozoficzno-społecznych, jakie określały wszelkie przemiany w literaturze i kulturze białoruskiej końca XIX wieku z ich pytaniem o sens ludzkiego życia, byt jednostki, o kierunek rozwoju i dążenia społeczeństwa. Świat wiejskiej społeczności, styl życia, realia obyczajowe i dorobek kulturalny, moralne przesłanki, mentalność chłopska, zróżnicowana rzeczywistość wsi białoruskiej znajdowały się w centrum uwagi poety, spostrzegawczego obserwatora zjawisk społeczno-ekonomicznych swoich

1 R. Łużny, Dziedzictwo chrześcijańskiego Wschodu stowiańskiego a życie kulturalne w Polsce - wczoraj i dziś, „Zeszyty Naukowe UJ. Prace Historycznoliterackie” 1994, z. 89, s. 112 . 
czasów. Poetykę Bahuszewicza charakteryzują przede wszystkim zewnętrzne opisy prostego wiejskiego człowieka, jego działania, postępki, portrety, czyny, stały i wzruszający kontakt z przyrodą, która była dlań źródłem pojednania i zachwytu, podstawowych wartości moralnych i estetycznych. Psychologiczne i filozoficzne analizy, wewnętrzne rozterki i rozważania są jemu w zasadzie obce $\mathrm{w}$ trakcie obcowania z naturą, dostrzegania i doceniania piękna ziemi swoich rodzinnych stron.

W swoich utworach, łączących ideologię romantyczną z estetyką realistyczną, pokazujących życie, obyczaje, kulturę chłopską, Bahuszewicz wysuwał hasła i postulaty natury narodowej i społecznej, bronił języka białoruskiego i prawa do krzewienia białoruskiej świadomości narodowej. W twórczości poetyckiej wielokrotnie sięgał do literackich dokonań Adama Mickiewicza i innych romantyków, ale najczęściej w słowie, składni, sposobach obrazowania, rytmie wzorował się na tonach opowieści z lat dzieciństwa, trawestował wątki białoruskiej poezji ludowej, odwoływał się do różnorodnych gatunków twórczości ludu, wykorzystywał inspiracje ludowe i obserwacje folklorystyczne.

Utwory poetyckie Bahuszewicza stanowią interesujące źródło wiedzy o życiu chłopa białoruskiego, przedstawiają przeżycia i obyczaje, proste i swojskie sprawy, drobne i ogólnie znane wydarzenia. To poezja prosta i pełna miłości do świata dzieciństwa, rodzinnego pejzażu i domu ojczystego, zaściankowej zagrody i bliskiego krajobrazu. Opisywany przez Bahuszewicza konkretny i realny świat nie był upiększany, idealizowany, istniejące antagonizmy i przejawy niechęci i zawiści nie zostały pominięte. Autor zachowywał wierność przekazywanych zdarzeń, rysowanych obrazów, przedstawianych postaci, zwracając szczególną uwagę na socjalne położenie i moralne zalety chłopstwa, otaczającą ich przestrzeń życiową.

Zatem w centrum poetyckich zainteresowań Bahuszewicza znajdował się temat chłopski, świat rzeczywistości wiejskiej, a bohaterem większości tekstów stał się prosty chłop białoruski marzący o innym, lepszym życiu, pragnący przemian, ale niezwykle bezradny, biedny, zastraszony i bezsilny, nieumiejący walczyć i przekonywać do swoich racji. Bahuszewicz starał się, z uwagą i dbałością o szczegóły, poznać i zgłębić świat i duszę prostego ludu, wszechstronnie i dokładnie przedstawić codzienne życie wiejskich bohaterów, odnaleźć i odzwierciedlić najcenniejsze wartości zawarte w chłopskim etosie. Korzystając z tradycyjnych obrazów i wzorców ludowej twórczości, wierzeń ludowych, terminologii chrześcijańskiej, leksykalnych i składniowych zasobów mowy potocznej, Bahuszewicz rysował krajobraz i kraj także swego dzieciństwa, swojej młodości, rodzinną okolicę, ziemię i otaczającą rzeczywistość, codzienne realne przeżycia ludzkie, konkretne sprawy powsze- 
dniego bytu wiejskiego, autentyczne poglądy i przemyślenia przedstawicieli warstwy chłopskiej, ubogich mieszkańców wsi, związanych z ziemią i pracą na roli.

W wielu utworach poeta mówił o tym, iż w uciążliwym, ale bezradnym zmaganiu pokornych, ubogich, choć pracowitych wieśniaków ze złym losem, ciężką dolą towarzyszą im zawsze swojskie krajobrazy. Podkreślają one osobowość chłopa, tłumaczą jego portret wewnętrzny i zewnętrzny, życiowe wybory i moralny kodeks. Otaczającą chłopów przestrzeń wprowadza poeta za pomoca szczegółowych opisów, prezentujacych nie tylko topografie fikcyjnych zdarzen, ale taki்e zwracajacych uwage na estetyczne walory tej przestrzeni, czasem nawet bezpośrednie ${ }^{2}$, mówiąc o pejzażu konkretnym, nazwanym, a zarazem niejednoznacznym $i$ metaforycznym ${ }^{3}$, pełnym szczegółów, nazw i doznań zmysłowych.

Naszaja wioska „Sialawiczy” zwietca.

Byli uniaty kaliści dziady,

Dobraja wioska: staić pry reczce

I żywić ludcy u nas biaz biady.

Na drowy nia trudna i wyhany jość... ${ }^{4}$

Dla Bahuszewicza, jak się wydaje, przestrzeń rzeczywista, czy - jeśli kto woli - fizyczna, w której sie poruszam, w której żyje, która tak czy owak porzadkuje, i przestrzeń, która wprowadzam w pewien myślowy porzadek, której nadaje różne sensy, w której dostrzegam coś więcej niż uktad elementów ściśle wymienialnych ${ }^{5}$, a więc materialnych miała wymiar również duchowy, związany ze wspomnieniami, myślami, refleksjami i przeżyciami. W tej przestrzeni wiejskiej rzeczywistości istotne miejsce zajmują chłopi, stanowiąc integralną część świata przyrody. Znają doskonale prawa natury, działają zgodnie $\mathrm{z}$ nimi, podporządkowując się i przestrzegając $\mathrm{w}$ trakcie całorocznych cyklicznych prac na roli. Czując więź z ziemią dostrzegają równocześnie i piękno otaczającej ich przyrody, uroki rodzimych pejzaży, urodę najbliższej okolicy.

2 A. Martuszewska, Od „Dzikiej” do „Dzikuski”. Przemiany funkcji natury w powieści. [w:] Przestrzeń i literatura. Studia pod red. Michała Gtowińskiego i Aleksandry Okopień-Głowińskiej. Tom poświęcony VIII Kongresowi Slawistów, Warszawa, PAN 1978, s. 213.

3 M. Baranowska, Muza krajobrazu ojczystego, [w:] O twórczości Jarosława Iwaszkiewicza, pod red. Aliny Brodzkiej, Kraków - Wrocław 1983, s. 109.

4 Smyk Białoruski Szymona Reǔki z pad Barysowa, Poznań 1894, s. 36.

5 M. Głowiński, Przestrzenne tematy $i$ wariacje, [w:] Przestrzeń..., op. cit., s. 79. 
Skaŭronaczki Boha chwalać,

A pastuszki ahoń palać,

A i słonaczka pryhreła;

Aż mnie ŭ duszy pajaśnieła.

Da południa iszli hetak

Pry darozie szmat i kwietak.

To praleski, to sasonka ${ }^{6}$.

W chłopskiej rzeczywistości rysowanej przez poetę ważną rolę odgrywa ziemia $^{7}$, która dla wiejskich bohaterów jest wartością nadrzędną, kształtuje ich postawy, motywy i formy codziennego postępowania, działania, uzasadnia wszelkie uczucia, reakcje i wybory. Z przywiązania do ziemi rodzinnych stron i okolic wynika rytm życia bohaterów, kształtuje się ich psychika, poglądy i postawy życiowe, przyzwyczajenia i nawyki utrwalone historycznie, w przeszłości przez ojców i dziadów, ich wiarę i specyfikę życia społecznego i religijnego.

Z motywem ziemi związany jest u Bahuszewicza motyw domu, chatki jako przestrzeni określającej granice chłopskiej egzystencji. Obraz chatki, otaczających ją drzew istnieje dla bohaterów Bahuszewicza w przestrzeni rzeczywistej, niezależnej od ich świadomości, w życiu realnym, codziennym, ale też i w przestrzeni symbolicznej, w lakonicznych, emocjonalnych, bardzo lirycznych wspomnieniach, w opisach pełnych tęsknoty i najdrobniejszych szczegółów, tworząc schemat uniwersalny tego motywu, nadając mu uogólniający charakter.

Biednaś maja chatka rozsiełasia z kraju,

Mież piaskoŭ, kamienniaŭ, la samaho haju,

Kiepskaż maja chatka, podwalina shniła,

I dymna i zimna, a mnie jana miła:

$\ldots$

Na strasie moh wyras, na machu biarozka.

Milszaja mnie chatka, jak czużaja wioska ${ }^{8}$.

W opisach chłopskiej rzeczywistości widoczny jest związek Bahuszewicza i jego bohaterów ze światem przyrody, która otaczała poetę od dzieciństwa, była jego naturalnym środowiskiem, jak i samoistna twórczość lu-

6 Dudka Białaruskaja Macieja Buraczka, Kraków 1891, s. 60.

7 Na temat ziemi zob.: I. Rudziewicz, Kult ziemi w twórczości Franciszka Bohuszewicza, [w:] Białorutenistyka Białostocka. Tom 1, pod red. Haliny Twaranowicz, Białystok 2009 , s. $75-83$.

8 Dudka.., op. cit., s. 20, 21. 
dowa, wpływająca na postrzeganie świata, podejście do spraw ludzi wsi, ich problemów i przeżyć. Rysując obrazy autentycznej wsi białoruskiej z jej krajobrazami i realiami, chłopskimi bohaterami i wiejskimi zwyczajami, Bahuszewicz zwracał również uwagę na różnorodne postaci rzeczywiście obecne w krajobrazie białoruskiej wsi popańszczyźnianej. Są to „panowie”, żydzi, popi, księża, biedacy, nierozerwalnie związani z życiem wsi, spleceni z losami wiejskich mieszkańców, umiejący razem z nimi grać i śpiewać przy wtórze instrumentów ludowych (dudka, skrzypce).

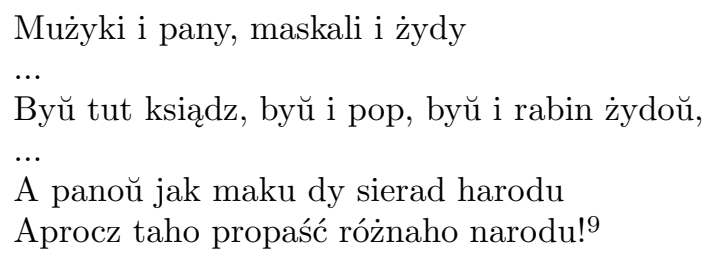

Skupiając uwage na rzetelnych opisach chłopskiej przestrzeni życiowej Bahuszewicz sięga do pierwiastków poezji ludowej, wykorzystując i wprowadzając jej elementy do swoich utworów. Występuje w nich muzykalność, wyrażona zarówno w treści, jak i w formie wierszy (ballady, dumki, elegie, kołysanki, pieśni, sielanki), naśladowanie dźwięków różnych instrumentów ludowych (cymbały, dudka, samahrajka, skrzypce, smyk, żalejka), stosowanie powtórzeń (Durny mużyk jak warona; Kiepska budzie!; Luli, synok, luli, luli!; Oj hora $\dot{z}$ majo! i in.), wykorzystywanie motywów i wątków z baśni i podań ludowych (np. kwiat paproci, siła nieczysta, skarby, zaprzedanie duszy diabłu i in.). Skupieniu uwagi na określonym wiejskim wycinku ówczesnej rzeczywistości sprzyjały również pojawiające się groteskowe zwroty i słowa z gwary wiejskiej, elementy chłopskiego humoru, spiętrzenie fantastycznych i nieprawdopodobnych sytuacji, opisy zwyczajów, obrzędów i obyczajów ludowych, a także uwidoczniana w sposób bezpośredni lub pośredni postawa religijna ${ }^{10}$ chłopów, będąca częścią, elementem narodowej tradycji, ludowej obrzędowości i kultury, punktem oparcia w dylematach życiowych.

Czerpiąc z własnego doświadczenia życiowego i zawodowego, z obserwacji i znajomości wiejskiego środowiska, Bahuszewicz wielokrotnie zwraca uwagę na życie materialne i ekonomiczne, religijne i obyczajowe warstwy

\footnotetext{
9 Tamże, s. $15,16$.
}

$10 \mathrm{Na}$ temat wiary i religii zob.: I. Rudziewicz, Atmosfera religijności w poezji Franciszka Bahuszewicza, „Acta Polono-Ruthenica II”, WSP Olsztyn 1997, s. 163-176; Taż, Znaczenie religii w życiu spoteczności wiejskiej w utworach poetyckich Franciszka Bahuszewicza, „Acta Albaruthenica 10". Profesorowi Aleksandrowi Barszczewskiemu na 80-lecie, Warszawa 2010, s. 189-195. 
chłopskiej, przekazując swoje dociekliwe obserwacje rzeczywistości społecznej, położenia ludu białoruskiego, chłopskiej bliskości, jedności, zespolenia i więzi z naturą, wykorzystując w tym celu różnorodne formy ekspresji artystycznej, środki poetyckie, w tym antropomorfizację zjawisk przyrody. To zespolenie losu chłopa z siłami natury, z przyrodą staje się jego optymistyczną wiarą w lepsze życie, w możliwość przebudzenia, odrodzenia i odnowy człowieka, jak to odbywa się w wiecznym świecie przyrody.

Nia tuży biarozka, świet z nami nia zhinie,

Wiecier jak pawieje szyszeczki rozkinie,

Choćby ty zasochła, - wyraście was bolej...

Piarastaniem płakać my nad swojej dolaj!11

W utworach poetyckich Bahuszewicz tworzył własną wizję wsi, wiejskiej przestrzeni pełnej cierpienia i ciężkiej pracy, ale również przepojonej wiarą i przywiązaniem do ziemi, pełną historycznych wspomnień i nowych marzeń. Przestrzeń geograficzna, przyrodnicza, przestrzeń ziemi lat dzieciństwa jest zarówno ziemią smutku i trudu, jak i ziemią marzeń, religijnych uniesien, radości i zabaw. W swoich poetyckich opisach Bahuszewicz wielokrotnie stosuje kontrasty, przeciwstawiając przestrzeń chłopską, gdzie mieszkańcy żyją biednie, ale zgodnie z naturą, z prawami przyrody - przestrzeni dworskiej, pańskiej, gdzie trwają zabawy i hulanki, ekonomiczne konsekwencje których ponosi lud gminny.

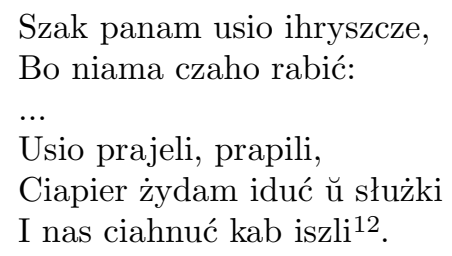

Dla bohaterów Bahuszewicza nie do pomyślenia jest sposób życia panów, pozbywanie się własnej ziemi, swego majątku. Dla nich dom-chatka to pewny i trwały punkt związany z miejscem urodzenia, wolnym od skomplikowanych spraw. Jest to przestrzeń egzystencjalna, istniejąca w rzeczywistej przestrzeni geograficznej, w zasięgu wzroku, wśród drzew, na ziemi rodzinnej. Jest to również przestrzeń duchowa, występująca we wspomnieniach, wyobrażeniach, tęsknotach, w pamięci. Widocznym znakiem bezpieczeństwa, wolności, bliskości, uczuć przywiązania do najbliższych i otaczającej przyrody staje się obraz chatki, obraz domu, który jest przestrzenią

11 Dudka..., op. cit., s. 30.

12 Smyk..., op. cit., s. 35, 36. 
zorganizowana moralnie, ciasno otoczona symboliczna linia granicy, enklawa skupiajaca najbardziej intymne uczucia, wypetniana wysokimi wartościami humanistycznymi. To prywatne sacrum jest miejscem osobistej wolności człowieka, miłości rodzinnej, przestrzenia bezpieczeństwa, obiektem tęsknoty $i$ celem powrotu ${ }^{13}$.

Ja nia kinu chatu, choć wy mianie reżcie, Nia pajdu da was ja, chibie u areszcie.

A choć siłaj nawiet adarwalib z domu,

Kaliści wiarnuŭsiab jak miadźwiedź da łomu.

Zawalitca j chata, zarastuć pakosy,

Usiob ja wiarnuŭsia, choć hoły, da bosy!14

Poezja, proza i publicystyka stają się dla Bahuszewicza formą aktywnych działań, orężem walki w sprawach narodowych, społecznych, ekonomicznych i politycznych. Następuje intensywne zainteresowanie poety białoruskim folklorem, życiem, obyczajami, obrzędami, kulturą i mentalnością białoruskiego chłopa, pojawiają się próby tworzenia w języku ludu, z wykorzystywaniem sposobów obrazowania, rytmiki, składni i problematyki zaczerpniętej z ludowych opowieści. „Poezja ludowa jako poezja prymitywna jest formułowaniem sądu nie według tego, co widzi oko poety, ale według uniwersalnego, synkretycznego porządku, jaki z tradycji kulturowej dziedziczy jego pamięć" ${ }^{15}$, sięgająca do obserwacji, przeżyć, wspomnień z lat dzieciństwa i młodości w konkretnej realnej rzeczywistości wiejskiej, w chłopskiej przestrzeni przeważnie wokół domu-chatki.

A kiń wokam na chatu maju:

I ciacze, i hnije, i krywaja,

U siaradzinie hnoj, i staić na hnaju,

I dziǔksia ja sam - jak trywaje?

Nie dziwisia panok, jak żywu, -

Mnie nichto nia pamoh budawać.

Choć laniwym u świecie sływu,

A mahu swiet karmić - hadawać ${ }^{16}$.

13 T. Michałowska, Wizje przestrzeni w liryce staropolskiej (rekonesans), [w:] Przestrzeń..., op. cit., s. 115.

14 Dudka..., op. cit., s. 21.

15 Kultura, literatura, folklor, red. M. Graszewicz, J. Kolbuszewski, Warszawa 1988.

16 Smyk..., op. cit., s. 30-31. 


\title{
РЭЗ Ю $\mathrm{M}$ \\ ЖЫЦЦЁВАЯ ПРАСТОРА СЯЛЯН Ў ПАЭТЫЧНЫХ ТВОРАХ ФРАНЦІШКА БАГУШЭВІЧА
}

На падставе некаторых твораў беларускага паэта Францішка Багушэвіча у артыкуле прадстайлены адносіны герояў-сялян да акружаючай іх рэчаіснасці. Звернута ўвага на адносіны герояў да прыроды, даляглядаў роднай зямлі, ваколіц і сваёй хаты.

Ключавыя словы: сялянства, паэтычныя творы, жыццёвая прастора, прырода, хата, зямля.

\author{
S U M M A R Y \\ PEASANT'S LIVING SPACE \\ IN POETIC WORKS WRITTEN BY FRANTSISHEK BAKHUSHEVICH
}

The analysis of works written by a White Russian poet Frantsishek Bakhushevich reveals an attitude of peasant's heroes to the surrounding rural reality. The attention is paid to heroes' approach to nature, home landscape, surrounding and a house-cottage.

Key words: peasants, poetic works, house-cottage, living space, attachment. 